\title{
Introduction to the special issue in honor of Nobel Laureate Angus Deaton: "consumption, poverty and inequality in the household"
}

\author{
Climent Quintana-Domeque ${ }^{1}$
}

Received: 10 November 2017 / Accepted: 27 December 2017 / Published online: 19 January 2018 (C) Springer Science+Business Media, LLC, part of Springer Nature 2018

It is a great honor for me to introduce this special issue in Honor of Nobel Laureate Angus Deaton "Consumption, Poverty and Inequality in the Household". Angus has had a major influence on my research, and I have been very fortunate to have him as teacher, mentor and co-author. His contributions to economics range from theoretical insights and econometric contributions to policy relevant empirical findings. This special issue reflects how the work by Angus has been and continues to be a great source of inspiration for economic research, and in particular for the theoretical and empirical analysis of household behavior.

The first two articles are related to one of Angus' seminal works, his study with Christina Paxson (Deaton and Paxson 1998), showing the so-called Deaton and Paxson puzzle, that at constant per capita total expenditure, the per capita demand for food decreases with household size. In the first article, Crossley and Lu investigate whether returns to scale in food preparation can resolve this puzzle. They show that a key requirement is that foods are heterogeneous in time costs. Using detailed food expenditure and time use data from Canada-the 1992 and 1996 Canadian Food Expenditure Survey and the detailed time use diaries that are part of the 1998 Canadian General Social Survey-they present evidence consistent with larger households shifting to more time intensive foods. In the second article, John Gibson and Bonggeun Kim examine bulk discounts by using individual transaction records from household expenditure diaries in urban Papua New Guinea, which contain information on expenditure, quantity, brand, unit size and number purchased by transaction. They estimate the bulk discount schedule for four foods that make up one-third of the total food budget (rice, chicken, canned meat and canned fish), and find that the bulk discount schedule is fairly flat with respect to household size. The authors conclude that bulk discounts cannot provide an explanation for the Deaton and Paxson puzzle.

Climent Quintana-Domeque

climent.quintana-domeque@economics.ox.ac.uk

1 Department of Economics, University of Oxford, Manor Road, Oxford OX1 3UQ, UK 
The third article, by Dwayne Benjamin, Loren Brandt, Brian McCaig and Nguyen Le Hoa, can be linked to Angus' masterpiece on the analysis of household surveys (Deaton 1997) and his work alerting that program evaluation is, if anything, a very complex and difficult enterprise, even in the presence of randomization (Deaton 2010). The authors investigate whether a land reform program led to higher incomes for ethnic minority households in Vietnam, and conclude that: first, there was substantial deviation from the planned program parameters - many eligible households did not receive land, while ineligible households often did; second, simple transfers of land are limited as a mechanism for improving the living standards of ethnic minorities.

The fourth, fifth and sixth articles can be connected to Angus' work on wellbeing, mortality and inequality, from his work on life satisfaction and income inequality (Deaton 2003, 2008; Deaton and Stone 2013) to his studies on (child) mortality (Bozzoli et al. 2009; Cutler et al. 2006; Deaton and Lubotsky 2003) and alcoholrelated adult mortality (Case and Deaton 2015). In the fourth article, Xiaoyan Lei, Yan Shen, James P. Smith and Guangsu Zhou use the 2012 wave of China Family Panel Studies national representative data to disentangle relationships between economic inequalities and life satisfaction. Their four main findings are: (1) economic inequalities in general are negatively associated with life satisfaction, after controlling for household absolute and relative levels of economic resources and other personal characteristics; (2) greater economic resources at the household level improve life satisfaction, in particular in urban areas compared to rural places; (3) economic resources of neighbors in the same county measured by relative expenditure appear to have little effect on life satisfaction; (4) inequality may be associated with life satisfaction through changing one's aspirations.

In the fifth article, by Vellore Arthi and James Fenske, the authors use historical and modern data on the Igbo ethnic group in Nigeria to examine how the practice of polygamy - through household organization, features, and behaviors unique to this form of marriage - correlates with child survival. They find a statistically significant positive relationship between polygamy and child mortality in the modern period. However, in historical data the relationship, while positive, turns to be statistically insignificant. They show that the positive correlation is consistent with an important role for selection (on unobservable characteristics) into polygamy.

In the sixth article of this special issue, Martina Menon, Federico Perali and Luca Piccoli investigate whether consumption of alcohol affects the distribution of resources among household members and their level of wellbeing in Italy. They test this by introducing a new collective complete demand system with individual Engel effects. The authors show that, apart from the dramatic consequences of alcohol poisonings in terms of mortality-in the United States (together with drug poisonings) they largely account for a deterioration of the health status of middle-aged white non-Hispanic men and women between 1999 and 2013 (Case and Deaton 2015)_alcohol consumption can have secondhand effects. Their estimates indicate that a high level of alcohol consumption of one household member significantly affects the allocation of household resources.

The seventh article, by Pierre-André Chiappori can be related to work by Angus with Martin Browning and Margaret Irish (Browning et al. 1985), one of the first studies in jointly analyzing labor supply and consumption in a dynamic framework with uncertainty. The author highlights that at the core of any empirical analysis of 
household behavior (such as a model of household labor supply) is the need to reconcile the precision of theoretical, deterministic predictions based on specific functional forms with the apparent randomness of data. While these discrepancies are typically attributed to random errors and/or unobserved heterogeneity, Pierre-André Chiappori offers an alternative explanation: in some circumstances, optimal household behavior entails randomized household decisions. He focuses on a household that faces discrete labor supply options and shows that even in the case of concave, i.e., risk-averse, preferences, randomization over labor supply may be Pareto optimal, and this has nothing to do with the distinction between unitary and collective models.

The wide range of topics and approaches covered by the articles in this special issue, from consumption to mortality and from purely empirical studies to purely theoretical ones, reflects Angus' enormous influence, and I am sure the reader will enjoy reading these articles.

It has been a great pleasure to serve as a Guest Editor for this special issue, and I would like to thank Professor Shoshana Grossbard (Editor-in-chief) for offering me such an opportunity. The analysis of household behavior is fundamental in our understanding of economics, both in developed and developing countries, and I am convinced that the Review of Economics of the Household will continue publishing new empirical and theoretical studies on the causes and consequences of consumption, poverty and intra-household inequality.

\section{Compliance with ethical standards}

Conflict of interest The author declares that he has no conflict of interest.

\section{References}

Bozzoli, C., Deaton, A., \& Quintana-Domeque, C. (2009). Adult height and childhood disease. Demography, 46(4), 647-669.

Browning, M., Deaton, A., \& Irish, M. (1985). A profitable approach to labor supply and commodity demands over the life cycle. Econometrica, 53(3), 503-544.

Case, A., \& Deaton, A. (2015). Rising morbidity and mortality in midlife among White Non-Hispanic Americans in the 21st century. Proceeding of the National Academy of Sciences of the United States of America, 112(49), 15078-15083.

Cutler, D., Deaton, A., \& Lleras-Muney, A. (2006). The determinants of mortality. Journal of Economic Perspectives, 20(3), 97-120.

Deaton, A. (1997). The Analysis of Household Suveys. A Microeconometric Approach to Development Policy. Baltimore, MD: World Bank Publications, The Johns Hopkins University Press.

Deaton, A. (2003). Health, inequality, and economic development. Journal of Economic Literature, 41(1), $113-158$.

Deaton, A. (2008). Income, health, and well-being around the world: Evidence from the Gallup World Poll. Journal of Economic Perspectives, 22(2), 53-72.

Deaton, A. (2010). Instruments, randomization, and learning about development. Journal of Economic Literature, 48(2), 424-455.

Deaton, A., \& Paxson, C. (1998). Economies of scale, household size, and the demand for food. Journal of Political Economy, 106(5), 897-930.

Deaton, A., \& Lubotsky, D. (2003). Mortality, inequality and race in American cities and states. Social Science and Medicine, 56(6), 1139-1153.

Deaton, A., \& Stone, A. (2013). Two happiness puzzles. American Economic Review, Papers and Proceedings, 103(3), 591-597. 